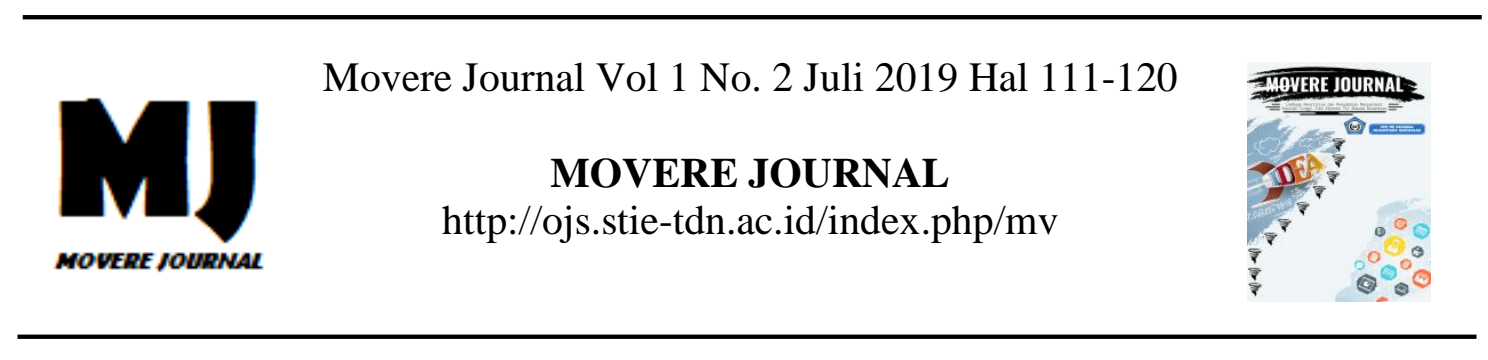

\title{
PENGARUH KEMASAN PRODUK SUSU BEAR BRAND TERHADAP KEPUTUSAN PEMBELIAN KONSUMEN PADA PT. OZE POWER SWITCH DI MAKASSAR
}

\author{
Andi Asad Ridjal Nur ${ }^{1)}$, Andi Rifqah Purnama Alam ${ }^{2)}$ dan Anggi ${ }^{3)}$ \\ STIE Tri Dharma Nusantara
}

\begin{abstract}
Abstrak : Penelitian ini bertujuan untuk mengetahui pengaruh Kemasan susu Bear Brand terhadap keputusan pembelian konsumen pada PT.Oze Power Switch Makassar. Data yang digunakan dalam penelitian ini adalah data primer dan data sekunder. Metode yang digunakan yaitu deskriptif jawaban hasil kuesioner dengan skala likersdan analisis statistik berupa analisis regresi sederhana, koefisien korelasi, koefisien determinasi, serta uji t. Hasil penelitian menunjukkan bahwa analisis regresi yang didapatkan persamaan $\mathrm{y}=8,09+0,65 \mathrm{x}$ serta hasil analisis koefisien korelasi $a=8,09 b=0,65, r_{x y} 0,41$ dan determinasi $r_{x y}^{2} 0,1681$ atau $16,81 \%$ serta diperoleh t hitungsebesar 3,272 lebih besar dari pada $t_{\text {tabel }} 1,674$ (3,272 > 1,674)yang artinya terdapat pengaruh kemasan produk susu Bear brand terhadap keputusan pembelian konsumen pada PT. Oze Power Switch Makassar.
\end{abstract}

Kata kunci: kemasan produk, keputusan pembelian

\section{PENDAHULUAN}

Kemasan produk digunakan untuk mengidentifikasi produk.Hal ini memainkan peran penting dalam menarik konsumen. Grafis eye catching membuat produk menonjol dirak dan menarik konsumen. Grafis dapat mempengaruhi melalui warna dan garis yang dicetak pada kemasan dengan tanda-tanda dan simbol yang diletakkan.Hologram dan kombinasi dari berbagai bahan dapat mendorong konsumen untuk menyentuh paket, sehingga membuat konsumen untuk mencoba produk.Apabila kemasan produk rendah, maka ketertarikan konsumen untuk membeli juga menjadi rendah, dan bila kemasan produk menarik, maka ketertarikan konsumen dalam membeli juga menjadi tinggi. diharapkan konsumen, maka konsumen bisa jadi tidak mau membeli.

Fenomena susu Bear brand adalah dimana yang kita lihat dan ketahui bahwa susu Bear brand bukan cuma dari segi kemasannya yang aman dan kuat tetapi yang perlu kita ketahui juga susu Bear brand adalah susu murni yang banyak mengandung protein, vitamin dan lemak sehingga baik untuk pertumbuhan dan menjaga kesehatan, yang dimana ini menjadi pembeda adalah susu sapi disini melewati proses sterilisasi yang murni. Proses sterilisasi, dilakukan dengan cara memanaskan susu sampai dititik didih. Yang pada akhirnya menyebabkan bakteri maupun kuman maupun sporanya mati.

Berdasarkan dari latar belakang di atas maka peneliti tertarik mengambil judul "Pengaruh Kemasan 
Produk Susu Bear Brand Terhadap Keputusan Pembelian Konsumen Pada PT. Oze Power Switch Makassar. Tujuan penelitian ini adalah untuk mengetahui pengaruh kemasan produksusu Bear Brand terhadap keputusan pembelian Konsumen pada PT.Oze Power Switch di kota Makassar.

\section{LANDASAN TEORI}

\section{Indikator Kemasan}

Kemasan produk merupakan ciri khas dari sebuah produk yang akan dipasarkan oleh perusahaan, indikator ini dapat diukur melalui indikator kemasan produk Menurut Lamb (2001:432), terdapat 3 indikator:

1. Memuat dan melindungi produk

Yakni untuk memuat produk yang cair, dalam bentuk butiran, atau sebaliknya dapat dibagi. Pengemasan juga memungkinkan pabrik,grosir dan pengecer untuk memasarkan produk dalam jumlah tertentu. Perlindungan fisik adalah fungsi pengemasan lain yan jelas kelihatannya pada produk.

2. Promosi Produk.

Pengemasan melakukan lebih dari sekedar mengidentifikasikan suatu merek, mendaftar semua bahan, menspesifisikan ciri khas, dan memberi petunjuk. Suatu kemasan membedakan sebuah produk dari produk pesaing dan dapat mengasosiasikan suatu produk baru dengan kelompok keluarga produk dari pabrik yang sama.

3. Mudah menyimpan, Menggunakan Dan Kenyamanan.

Para grosir dan pengecer lebih memilih kemasan yang mudah untuk dikirim, ditimbun, dan disimpan pada rak, mereka juga suka kemasan yang melindungi produk, mencegah kebusukan dan kerusakan, dan memperpanjang usia pemanjangan produk.

\section{Keputusan pembelian}

Keputusan pembelian konsumen merupakan sebuah tindakan yang dilakukan konsumen untuk membeli suatu produk. Setiap produsen pasti menjalankan berbagai strategi agar konsumen memutuskan untuk membeli. Berikut pengertian keputusan pembelian konsumen yang dikemukakan oleh beberapa pendapat para ahli yang mereka kemukakan seperti di bawah ini.

Menurut Lamb (2001:188), Ketika membeli produk, secara umum konsumen mengikuti proses pengambilan keputusan seperti ditunjukkan sebagai berikut: pengenalan kebutuhan, pencarian informasi, evaluasi alternati, pembelian, dan perilaku pasca pembelian. Lima tahapan ini mewakili proses secara umum yang menggerakkan konsumen dari pengenalan produk atau jasa ke evaluasi pembeli.

Proses ini adalah petunjuk untuk mempelajari bagaimana konsumen membuat suatu keputusan. Sedangkan menurut Buchari (2004:97), keputusan pembelian yang dilakukan oleh konsumen, dipengaruhi oleh banyak hal. Demikian pola konsumen-konsumen, terbentuk karena pengaruh kebudayaan (Culture), Kelas sosial (Social class), keluarga (Family), dan Klub - klub (Referensi Group).

Dari pengertian keputusan pembelian konsumen diatas dapat diambil kesimpulan bahwa keputusan pembelian konsumen mengikuti sebuah proses yaitu pengenalan kebutuhan, pencarian informasi, evaluasi alternatif, pembelian, dan dan perilaku pasca pembelian dari kelima proses tersebut konsumen mengambil keputusa untuk membeli suatu produk, yang sebenarnya keputusan pembelian konsumen terdiri dari beberapa keputusan yang mendasari keputusan 
untuk membeli suatu produk barang ataupun jasa bukan hanya dari keputusan dari diri sendiri yang mempengaruhi keputusan pembelian.

\section{Faktor-Faktor Yang Mepengaruhi Keputusan Pembelian}

Konsumen dalam menentukan pembelian tidak lepas dari faktorfaktor keputusan pembelian konsumen, berikut beberapa faktor-faktor yang mempengaruhi keputusan pembelian menurut parah ahli yaitu:

Menurut Lamb (2001:201), proses pengambilan keputusan konsumen tidak bisa terjadi dengan sendirinya, sebaliknya masalah kebudayaan, sosial, individu dan psikologis secara kuat mempengaruhi keputusan tersebut. Merka memiliki pengaruh dari waktu konsumen menerima ransangan melalui perilaku pasca pembelian. Menurut Thamrin (2012:112), menjelaskan bahwa ada beberapa faktor yang mempengaruhi keputusan pembelian, yaitu :

1. Faktor Budaya, faktor yang mempunyai pengaruh yang paling luas dan mendalam terhadap perilaku konsumen yang di mana didalamnya terdapat : kultur, subkultur, dan kelas sosial pembeli.

2. Faktor Sosial, faktor yang dipengaruhi oleh kelompok acuan (kelompok referensi), keluarga, serta peran dan status sosial.

3. Faktor Pribadi, yaitu usia pembeli dan tahap siklus hidup, pekerjaan, kondisi ekonomi, gaya hidup, serta kepribadian dari diri pembeli.

4. Faktor Psikologis, faktor yang dimana pilihan prmbelian seseorang dipengaruhi oleh empat faktor utama yaitu: motivasi, persepsi, pengetahuan (learnngi), serta keyakinan dan sikap.

\section{Indikator Keputusan Pembelian}

Dalam menentukan pilihan konsumen dapat diukur oleh indikator keputusan pembelian. Menurut Kotler (2008:235), keputusan pembelian dapat diidentifikasi melalui indikatorindikator sebagai berikut:

\section{Pengenalan masalah}

Proses dimulai ketika pembeli mengenali masalah atau kebutuhan. Keputusan tersebut dapat dicetuskan ransangan internal atau external.

2. Pencarian Informasi

Konsumen yang teransang kebutuhannya akan terdorong untuk mencari informasi yang lebih banyak tentang produk. Dan hal ini Yang menjadi perhatian utama perusahaan pemasar adalah sumber-sumber informasi utama yang menjadi acuan pembelian konsumen dan pengaruh yang relatif setiap sumber terhadap keputusan pembelian konsumen.

\section{Evaluasi Alternatif}

Bagaimana konsumen mengolah informasi merek yang bersaing dan membuat penilaian akhir? Tidak ada proses evaluasi tunggal sederhana yang digunakan oleh semua konsumen atau oleh satu konsumen dalam semua situasi pembelian.

\section{Keputusan pembelian}

Dalam tahap evaluasi, para konsumen membentuk preferensi atas merek merek dalam kumpulan pilihan. Konsumen dapat juga membentuk niat untuk membeli merek yang paling disukai.

\section{Perilaku pasca pembelian}

Setelah pembelian, konsumen mungkin mengalami ketidak sesuaian karena memerhatikan fitur-fitur tertentu yang mengganggu atau mendengar hal-hal yang menyenangkan tentang merek lain, dan akan selalu siaga terhadap 
informasi yang mendukung keputusannya.

\section{Hubungan Kemasan Produk Terhadap Keputusan Pembelian}

Dalam membuat kemasan produk yang menarik mengarah kepada tujuan perusaahan dalam mempengaruhi keputusan pembelian. Kemasan yang menarik dapat membuat keputusan pembelian hal ini sesuai dengan diungkapkan oleh ahli yaitu Menurut Shimp (2003:307), mengatakan bahwa dalam marketing/pemasaran kemasan produk merupakan sarana komunikasi produk, kemasan menjadi sarana terbaik yang mendorong konsumen untuk membeli sebuah produk.

Dalam proses keputusan pembelian konsumen menentukan pilihan terhadap suatu produk Hubungan kemasan yang dikemukankan oleh Kotler dan Amstrong (2008:275) Kemasan merupakan dan memproduksi wadah atau pembungkus suatu produk. Bungkus atau kemasan yang menarik akan memberikan nilai plus kepada konsumen yang sedang membedakan produk yang mutunya hampir sama.

\section{Hipotesis}

Berdasarkan masalah pokok yang dikemukankan diatas, maka penulis menyimpulkan hipotesis sebagai berikut :"Diduga kemasan produk susu Bear Brand berpengaruh terhadap keputusan pembelian konsumen pada PT. Oze Power Switch di Makassar".

\section{METODE PENELITIAN}

Penelitian ini dilakukan pada Perusahaan PT.OzePowerSwitch yang beralamat di Jl. K.S Tubun No.12 Makassar. Waktu penelitian yang dilakukan selama 3 bulan yaitu dimulai pada bulan Februari sampai dengan bulan April 2018.

\section{Metode Pengumpulan Data}

Adapun metode pengumpulan data yang akan digunakan untuk menunjang dalam pelaksanaan penelitian ini untuk pengumpulan sampel adalah sebagai berikut:

1. Penelitian Ke perpustakaan (Library Research)

2. Penelitian Lapangan(Field Research)

Pengumpulan data melalui penelitian lapangan dilakukan dengan mengadakan pengamatan ke lokasi penelitian. Teknik yang digunakan adalah:

1. Observasi

2. Wawancara

\section{Populasi dan Sampel}

Menurut Sugiyono (2017:80), menyatakan bahwa "populasi adalah wilayah generalisasi yang terdiri dari objek atau subjek yang mempunyai kualitas atau karakteristik tertentu yang ditetapkan oleh peneliti untuk dipelajari dan kemudian ditarik kesimpulannya.

Berdasarkan pengertian tersebut diatas, maka yang akan ditentukan untuk menjadi populasi dalam penelitian ini adalah orang-orang atau konsumen yang pernah menggunakan produk susu Bear Brand yang didistribusikan olehPT.OzePower Switch yang ada di Kota Makassar.

Sampel adalah bagian dari jumlah dan karakteristik yang dimiliki oleh populasi tersebut. Apabila populasi besar, dan peneliti tidak mungkin mempelajari semua yang ada pada populasi, misalnya karena keterbatasan dana dan waktu, maka peneliti dapat menggunakan beberapa sampel yang diambil dari populasi itu. Apa yang dipelajari dari sampel itu, kesimpulannya akan diberlakukan untuk populasi menurut (Sugiyono, 2017:81).

Menurut Frankel dan Wallen (1993:92), menyarankan besar sampel minimum yaitu: 
1. Untuk penelitian deskriptif sebanyak 10 sampel.

2. Untuk penelitian korelasional sebanyak 50 sampel.

3. Untuk penelitian kausalperbandingan 30/group.

4. Untuk penelitian eksperimental sebanyak 30/15 per group.

Berdasarkan teori diatas, maka dalam penelitian ini akan menggunakan sampel responden konsumen susu Bear Brand dengan populasi sebanyak 55 orang.

\section{Metode Analisis Data}

Dalam proses penelitian, diperlukan teknik skala pengukuran. Skala pengukuran nantinya akan sangat membantu peneliti dalam mengolah data yang nantinya dihasilkan dari kuesioner. Adapun skala pengukuran yang dipilih oleh peneliti dan akan digunakan dalam penelitian ini adalah skala Likert. Skala Likert digunakan untuk mengukur sikap, pendapat, dan persepsi seseorang atau sekelompok orang tentang fenomena sosial. Dalam penelitian, fenomena sosial ini ditetapkan secara spesifik oleh peneliti, yang selanjutnya disebut sebagai variable penelitian. Dengan menggunakan skala Likert, maka variabel diukur dijabarkan menjadi indikator kemudian indikator tersebut dijadikan sebagai titik tolak untuk menyusun instrumen yang dapat berupa pernyataan atau pertanyaan (Sugiyono, 2017:93).

Berdasarkan hasil kuesioner yang telah diberikan kepada responden dan telah diisi, melalui hasil analisis dengan menggunakan principal component analysis, kemudian skor atau nilai dari hasil perolehan kuesioner yang telah didapatkan dari para responden yang nantinya akan diolah. Adapun langkah-langkah itu yang nantinya digunakan dalam melakukan analisis dalam penelitian ini yaitu sebagai berikut:
1. Setiap indikator atau sub variable yang dinilai oleh responden diklasifikasi kedalam lima alternatif jawaban dengan menggunakan skala ordinal yang menggambarkan peringkat jawaban dari responden. Peringkat jawaban setiap indikator diberi skor antara 1 sampai dengan skor 5 .

2. Dihitung dari total skor setiap variable/sub variabel $=$ jumlah skor dari seluruh skor indikator variabel untuk semua jawaban dari responden

3. Dihitung skor setiap variabel/sub variabel $=$ rata-rata dari total skor semua responden.

4. Untuk mendeskripsikan jawaban dari responden digunakan juga statistik deskripsi seperti frekuensi dan ditampilkan di dalam bentuk tabel.

5. Untuk menjawab distribusi tentang masing-masing variabel penelitian ini digunakan tentang kriteria penelitian. Selanjutnya menetapkan peringkat dalam setiap variabel penelitian dapat dilihat dari perbandingan antara skor aktual dengan skor ideal. Skor aktual diperoleh melalui hasil perhitungan seluruh pendapat responden yang telah mengisi kuesioner yang telah dibagikan sebelumnya sesuai klasifikasi bobot yang diberikan yaitu skala 1 (satu) sampai 5 (lima) (1,2,3,4 dan 5), kemudian untuk mendapatkan hasil dari skor aktual tersebut akan diolah menggunakan analisis statistik.

Adapun klasifikasi skor tanggapan konsumen atau kategori yang dikemukakan oleh Sugiyono (2005:14), dan digunakan dalam penelitian ini adalah : 
Tabel 2. Kriteria skor tanggapan terhadap skor ideal.

\begin{tabular}{|c|c|}
\hline Kategori & Skor \\
\hline Sangat Baik (SB) & 5 \\
\hline Baik (B) & 4 \\
\hline Kurang Baik (KB) & 3 \\
\hline Tidak Baik (TB) & 2 \\
\hline $\begin{array}{c}\text { Sangat Tidak Baik } \\
\text { (STB) }\end{array}$ & 1 \\
\hline
\end{tabular}

Sumber: Sugiyono (2005:14)

Penentuan rentang mengacu pada skor yang digunakan yaitu banyaknya kelas interval dari angka 1 (satu) merupakan data terkecil besarnya $20 \%$, sedangkan data terbesar diperoleh dari angka 5 (lima) yang besarnya $100 \%$. Jadi rentang adalah $100 \%-20 \%=80 \%$ diperoleh interval yaitu $80 \%: 5=16$, sehingga penelitian untuk analisis masing-masing dari variable dalam bentuk tabel yang dikemukakan oleh Narimawati (2007:84), adalah sebagai berikut:

Tabel 3. Kriteria skor tanggapan responden terhadap skor ideal.

\begin{tabular}{|c|c|}
\hline Interval \% & Skor \\
\hline $84,01-100$ & Sangat Baik (SB) \\
\hline $68,01-84,00$ & Baik (B) \\
\hline $52,01-68,00$ & Kurang Baik (KB) \\
\hline $36,01-52,00$ & Tidak Baik (TB) \\
\hline $20,00-36,00$ & $\begin{array}{c}\text { Sangat Tidak Baik } \\
\text { (STB) }\end{array}$ \\
\hline
\end{tabular}

Sumber : Narimawati (2007:84)

\section{Analisis Regresi Sederhana}

Analisis regresi sederhana dalam penelitian ini nantinya akan digunakan untuk mengetahui pengaruh kemasan produk terhadap keputusan pembelian konsumen pada PT. OzePower Switch di kota Makassar.

Adapun rumusannya adalah :

Dimana :

$$
y=a+b x+e
$$

$$
\begin{aligned}
& \mathrm{X}=\text { Kemasan Produk } \\
& \mathrm{Y}=\text { Keputusan pembelian }
\end{aligned}
$$

$$
\begin{aligned}
& \mathrm{a}=\text { Konstanta } \\
& \mathrm{b}=\text { Koefisien Regresi } \\
& \mathrm{e}=\text { Standard error }
\end{aligned}
$$

Lanjutan perhitungan berikutnya untuk memperoleh nilai a dan $b$ digunakan rumus:

$$
\begin{gathered}
b=\frac{n\left(\sum X Y\right)-\left(\sum X\right)\left(\sum Y\right)}{n\left(\sum X^{2}\right)-\left(\sum X\right)^{2}} \\
a=\frac{\sum Y-b\left(\sum X\right)}{n}
\end{gathered}
$$

\section{Analisis Korelasi dan Koefisien}

Determinasi.

a. Koefisien korelasi digunakan untuk mengetahui Keputusan pembelianpada PT. OzePower Switch, dengan rumus sebagai berikut:

$$
r=\frac{n \cdot\left(\sum X Y\right)-\left(\sum X\right) x\left(\sum Y\right)}{\sqrt{n\left(\sum X^{2}\right)}-\left(\sum X\right)^{2}-\sqrt{n}\left(\sum Y^{2}\right)-\left(\sum Y\right)^{2}}
$$

Dimana:

$\mathrm{r}=$ Koefisien korelasi

$\mathrm{X}=$ Kemasan Produk

$\mathrm{Y}=$ Keputusan pembelian konsumen

$\mathrm{n}=$ Jumlah tahun data

b. Koefisien Determinasi $\left(r^{2}\right)$ di gunakan untuk mengetahui seberapa besar pengaruh variabel kemasan produk terhadap keputusan pembelian konsumen PT. Oze Power Switch yang satu dengan yang lainnya.

$$
\begin{aligned}
& r^{2}=\frac{n \cdot\left(\sum X Y\right)-\left(\sum X\right) x\left(\sum Y\right)}{\left.\sqrt{n\left(\sum X^{2}\right.}\right)-\left(\sum X\right)^{2}-\sqrt{n}\left(\sum Y^{2}\right)-\left(\sum Y\right)^{2}} \\
& \text { Dimana: } \\
& r^{2}=\text { koefisien determinasi }
\end{aligned}
$$

Tabel 4. Kriteria untuk mengetahui keeratan korelasi.

\begin{tabular}{|c|c|}
\hline $\begin{array}{c}\text { Interval } \\
\text { koefisien }\end{array}$ & $\begin{array}{c}\text { Tingkat } \\
\text { hubungan }\end{array}$ \\
\hline $0,80-1,000$ & Sangat Kuat \\
\hline $0,60-0,799$ & Kuat \\
\hline
\end{tabular}




\begin{tabular}{|c|c|}
\hline $0,40-0,599$ & Sedang \\
\hline $0,20-0,399$ & Lemah \\
\hline $0,00-0,200$ & Sangat Lemah \\
\hline
\end{tabular}

Sumber: Sugiyono (2016:184)

\section{Analisis Uji T}

Selanjutnya untuk menguji hipotesis yang telah ditentukan sebelumnya bahwa Kemasan Produk diduga berpengaruh terhadap Keputusan pembelian pada PT. Oze Power Switch. Maka peneliti akan melakukan uji $\mathrm{T}$ yaitu dengan membandingkan t-hitung yang telah dihasilkan dengan t-tabel derajat bebas (a)0,05. Adapun masing-masing kriteria pengujian terhadap hipotesis: Hipotesis: Ho : $b=0$ tidak ada pengaruh dengan $\mathrm{Ha}$

Ho : $b \neq 0$ ada pengaruh dengan $\mathrm{Ha}$

$$
t=\sqrt[r]{\frac{n-2}{1-r^{2}}}
$$

Keterangan:

a.Apabila t-hitung > t-tabel, maka Ho ditolak dengan $\mathrm{Ha}$ artinya terdapat pengaruh signifikan antara kemasan produk dengan Keputusan pembelian pada PT. Oze Power Switch.

b. Apabila t-hitung < t-tabel tidak terima dengan $\mathrm{Ha}$ artinya tidak terdapat pengaruh signifikan antara kemasan produk dengan Keputusan pembelian pada PT. Oze Power Switch.

\section{HASIL PENELITIAN DAN PEMBAHASAN}

\section{Analisis Kemasan PT. Oze Power Switch}

Dalam penelitian ini, analisis dimaksudkan untuk mengetahui seberapa besar tanggapan responden atas beberapa pertanyaan yang erat kaitannya dengan kemasan yang dihubungkan dengan keputusan pembelian konsumen pada PT. Oze Power Switch Makassar.

Hasil atas menunjukkan bahwa pencapaian persentase sebesar $87 \%$, sehingga jika dikaitkan dengan skor yang telah ditentukan sebelumnya, yaitu antara 81 sampai dengan 100, maka dapat dikatakan, bahwa kemasan Bear Brand termasuk sangat baik. Hal ini didasari oleh baiknya respon yang diberikan responden pada PT. Oze Power Switch di kota Makassar.

\section{Analisis Keputusan Pembelian Pada PT. Oze Power Switch}

Keputusan pembelian yang dilakukan oleh konsumen merupakan jawaban dari responden yangberhasil atau tidaknya perubahan kemasan produk yang telah dilakukan atau kemasan produk yang di terapkan oleh perusahaan. Terkadang perubahan atau penerapan kemasan produk yang dilakukan tidak terlalu berdampak positif terhadap pertumbuhan perusahaan karena tidak mempengaruhi keputusan pembelian yang akan dilakukan oleh konsumen. Berikut ini penulis ditampilkan pertanyaan kepada responden mengenai keputusan pembelian konsumen PT. Oze Power Switch Makassar.

Hasil analisa responden dapat menunjukkan bahwa pencapaian persentase sebesar $88 \%$, sehingga jika dikaitkan dengan skor yang telah ditentuskan sebelumnya yaitu antara 81 sampai dengan 100, maka dapat dikatakan bahwa keputusan pembelian yang dilakukan oleh konsumen terhadap produk PT. Oze Power Switch Makassar adalah Sangat Baik.

\section{PengaruhKemasan Produk Terhadap Keputusan Pembelian}

Untuk menganalisa pengaruh kemasan produk terhadap keputusan pembelian konsumen pada PT. Oze Power Switch Makassar, maka penulis menggunakan metode analisis secara (C) 2019 STIE TDN. All rights reserved 
statistik, yaitu metode regresi linear sederhana dan koefisien korelasi serta koefisien determinasi. Kemudian, untuk menguji hipotesis bahwa ada tidaknya pengaruh kemasan produk terhadap keputusan pembelian maka digunakan uji statistik koefisien korelasi.

1. Analisis regresi linear sederhana

Untuk menguji ada baiknya pengaruh kemasan produk terhadap keputusan pembelian konsumen, maka digunakan analisis regresi. Adapun bentuk persamaan adalah melalui rumus sebagai berikut:

$$
y=a+b x
$$

Untuk mendapatkan persamaanya, maka nilai $a$ dan $b$ harus ditentukan dengan menggunakan rumus sebagai berikut :

$$
\begin{aligned}
& a=\frac{\sum Y}{n}-\frac{b\left(\sum X\right)}{n} \\
& b=\frac{n\left(\sum X Y\right) s-\left(\sum X\right)\left(\sum Y\right)}{\left(n \sum X^{2}-\left(\sum X\right) 2\right.} \\
& \begin{array}{c}
a= \\
\frac{1226}{55}-
\end{array} \\
& \frac{0,65(1226)}{55} \quad b=\frac{55(27169)-(1226)(1215)}{55(27460)-(1226)^{2}} \\
& a= \\
& \frac{1215-796,9}{55} \\
& a=\frac{445,1}{55} \\
& a=8,09 \\
& \begin{array}{r}
b=\frac{1494295-1489590}{1510300-1503076} \\
b=\frac{4705}{7224} \\
b=0,65
\end{array}
\end{aligned}
$$

Dari perhitungan di atas, maka didapat persamaan regresi linear sederhana antara variabel $\mathrm{x}$ dan y adalah :

$$
\mathrm{Y}=\mathrm{a}+\mathrm{bx}
$$

a. Nilai regresi $\alpha=8,09$ artinya hasil kemasan produk

b. Nilai regresi $b=0,65$ artinya hasil keputusan pembelian

$$
Y=8,09+0,65 X
$$

Persamaan diatas dapat dijelaskan sebagai berikut: jika kemasan produk $(X)$ bertambah sebesar 1 satuan, maka diharapkan akan meningkatkan keputusan pembelian konsumen $(Y)$ sebesar 0,65 dan nilai konstanta sebesar 8,09 yang artinya, tanpa adanya variable kemasan produk $(X)$ maka keputusan pembelian konsumen $(Y)$ sebesar 8,09.

\section{Analisis koefisien korelasi (r)}

Tabulasi perhitungan kuesioner untuk mencari keterkaitan antara variabel kemasan produk terhadap keputusan pembelian Bear Brand pada PT. Oze Power Switch dapat dilihat dan jelaskan rumus berikut :

$$
\begin{aligned}
& r=\frac{n \sum X Y-\left(\sum X\right)\left(\sum Y\right)}{\sqrt{n \sum X^{2}-\left(\sum X\right)^{2} \cdot n \sum Y^{2}-\left(\sum Y\right)^{2}}} \\
& r=\frac{55(27169)-(1226)(1215)}{\sqrt{55(27460)-(1226)^{2} .55(27171)-(1215)^{2}}} \\
& r=\frac{1.494 .225-1.489 .590}{\sqrt{(1.510 .300-1.503 .076)(1.494 .405-1.476 .225)}} \\
& r=\frac{4.705}{\sqrt{7.224 x 18.180}} \\
& \quad r=\frac{4.705}{11.460 .031} \\
& r=0,41
\end{aligned}
$$

Hasil analisis diperoleh nilai koefisien korelasi 0,41 berada pada 0,40-0,599 dengan korelasi sedang, sehingga dapat disimpulkan bahwa terdapat pengaruh yang sedang antara variablekemasan produk terhadap variable keputusan pembeli konsumen.

3. Koefisien determinasi $\left(r^{2}\right)$

Untuk mengetahui besarnya hasil variable kemasan produk terhadap variable keputusan pembeli konsumen, dapat dihitung dengan rumus sebagai berikut:

$$
\text { Koefisien Determinasi (KD) }=r^{2}
$$

$$
\text { Koefisien Det erminasi }(\mathrm{KD})=r^{2}
$$

$$
=0,41 \times 0,41
$$




$$
\begin{gathered}
=0,1681 \text { atau } \\
16,81 \%
\end{gathered}
$$

Hasil dari determinasi $\left(r^{2}\right)$ adalah 0,1681 ini berarti bahwa kemasan produk mempengaruhi keputusan pembeli sebesar $16,81 \%$, dan sisanya $83,19 \%$ dipengaruhi oleh faktor lain yang tidak diteliti.

\section{Uji hipotesis (uji-t)}

Untuk membuktikan suatu hipotesis sekaligus menguji secara signifikasi atau tidaknya pengaruh antara variable kemasan terhadap variabel keputusan pembeli konsumen tersebut, maka digunakan uji statistik melalui uji-t, yaitu :

$$
t=\sqrt[r]{\frac{n-2}{1-r^{2}}}
$$

Dari perhitungan koefisien korelasi di atas, diketahui :

Nilai koefisien korelasi $(\mathrm{r})=0,41$

Taraf nyata $(\alpha)=0,05(5 \%)$

Nilai tabel memiliki derajat bebas $(\mathrm{db})$

$=\mathrm{n}-2$

$=55-2$

$=53$

Maka, $\boldsymbol{t}_{\text {tabel }(\mathbf{0 , 0 5 : 5 3 )}}=1,674$

Ho : $b=0$ tidak ada pengaruh dengan $\mathrm{Ha}$

Ho : $b \neq 0$ ada pengaruh dengan $\mathrm{Ha}$

$$
\begin{gathered}
\boldsymbol{t}_{\text {hitung }}=\sqrt[r]{\frac{n-2}{1-r^{2}}} \\
\boldsymbol{t}_{\text {hitung }}=\sqrt[0,41]{\frac{\mathbf{5 5 - 2}}{\mathbf{1 - ( 0 , 4 1 ) ^ { 2 }}}} \\
=\sqrt[0,41]{\frac{53}{1-(0,1681)}} \\
=\sqrt[\mathbf{0 , 4 1}]{\frac{53}{0,8319}}
\end{gathered}
$$

$$
\begin{aligned}
& =\sqrt[0,41]{63,709} \\
& =0.41 \times 7,981 \\
& =3,272
\end{aligned}
$$

Uji statistik melalui uji $\boldsymbol{t}_{\text {hitung }}$ diperoleh nilai sebesar $\boldsymbol{t}_{\text {hitung }} 3,272$ dan t-tabel sebesar 1.674.Karena $\boldsymbol{t}_{\text {hitung }}>$

$\boldsymbol{t}_{\text {tabel }}(3,272>1.674), \quad$ maka $H_{o}$ ditolak dan $H_{a}$ diterima. Artinya terdapat pengaruh yang signifikan antara kemasan dengan keputusan pembelian konsumen. Dengan demikian hasil yang diajukan dalam penelitian ini diterima.

Hasil perhitungan t-hitung dan gambar kurva hipotesis, diketahui bahwa variabel (kemasan produk) tersebut memiliki korelasi atau hubungan terhadap peningkatan variabel (keputusan pembelian). Hal ini ditunjukkan oleh keberadaan variable tersebut dengan t-hitung pada sebelah kanan kurva pengujian hipotesis dan memiliki nilai yang lebih besar dari nilai kritis $(1.674: a=0.10)$.

Hal ini juga memberikan petunjuk bahwa kedua variabel memiliki hubungan yang signifikan, artinya setiap perubahan yang terjadi oleh karena perlakuan peningkatan variabel kemasan produk, maka variabel lainnya, yaitu variabel keputusan pembelian dapat juga meningkat.

Hasil ini sesuai dengan pendapat Menurut Shimp (2003:307), mengatakan bahwa dalam marketing/ pemasaran kemasan produk merupakan sarana komunikasi produk, kemasan menjadi sarana terbaik yang mendorong konsumen untuk membeli sebuah produk. Hal ini sejalan dengan penelitian Ahmad zudhi Nento (2013) dengan judul "Pengaruh merek dan kemasan terhadap keputusan pembelian konsumen (studi kasus pada toko piasaronde)" dengan hasil yang didapatkan kemasan berpengaruh signifikan terhadap keputusan 
pembelian. Sedangkan Bayu Bakti Pranata (2013), "Pengaruh kualitas produk, kemasan, dan harga terhadap keputusan konsumen dalam pembelian produk kapal api di kec. Ngadi luwih kab. Kediri" Hasil penelitian kemasan berpengaruh signifikan terhadap keputusan pembelian kopi saset merek Kapal api.

\section{DAFTAR PUSTAKA}

Agus, Sachari, 2004. Seni Rupa Dan Desain. Jakarta : Gelora Aksara Pratama Erlangga.

Alma, 2004. Managemen Pemasaran Dan Pemasaran Jasa. Bandung : ALFABETA.

Amstrong, 2001. Prinsip-prinsip edisi kedua belas Jilid 1. Jakarta : Erlangga.

Fandy, Tjiptono, 2001. Strategi Pemasaran edisi pertama. Yogyakarta : Andi Ofset 2007. Strategi Pemasaran edisi kedua. Yogyakarta : Andi Ofset 2008. Strategi Pemasaran. Yogyakarta: Andi Ofset.

Fraenkel, J. \& Wallen, N. 1993. How to Design and evaluate research in education. (2nd ed). New York: McGraw-Hill Inc.

Kotler, 2008. Manajemen Pemasaran, Jakarta: PT Indeks.

dan Amstrong. 2008 Managemen Pemasaran. Jakarta: PT. Index kelompok Gramedia. dan Keller. 2008 Manajemen Pemasaran, PT. Indeks.

Indrawan, Rully dan Yaniawati, Koppy. 2014. Metodology penelitian kuantitatif, kualitatif, dan campuran untuk manajemen, pembangunan dan pendidikan. Anditama.

Lamb, Dkk . 2001 Pemasaran. Jakarta: Salemba Empat.
Malau, Harman. 2017. Teori Dan Aplikasi Pemasaran Era Tradisional Sampai Era Modernisasi Global. Bandung : ALFABETA

Rosnani. 2010. Perancanga Produk. Medang : Graha Ilmu

Swastha dan Irawan. 2001. Manajemen Pemasaran Moderen, Yogyakarta : LIBERTY

Shimp, Terance A. 2003. Periklanan, Promosi Aspek Tambahan Komunikasi jilid 1 edisi 5.Jakarta :Erlangga

Sugiyono,2017. Metode Penelitian, Bandung : ALFABETA. , 2005. Metode Penelitian Administrasi. Bandung: ALFABETA. , 2016. Metode Penelitian Kuantitatif Kualitatif dan R\&D. Bandung: ALFABETA

Thamrin, 2012. Manajemen Pemasaran. Jakarta : PT. Raja Grafindo Persada.

Umi Narimawati. 2007. Riset Manajemen Sumber Daya Manusia, Aplikasi Contoh dan Perhitungan. Jakarta : Agung Media.

Wicaksono, 2015. Pengaruh Merek dan Desain Terhadap Minat Beli Konsumen 